\title{
FAILURE OF RELAXIN IN THE TREATMENT OF SCLERODERMA
}

\author{
BY \\ J. E. JEFFERIS AND A. St. J. DIXON \\ From the Postgraduate Medical School, London
}

Relaxin (Hisaw, 1926) is an ovarian polypeptide hormone (Frieden and Hisaw, 1953), which appears in the serum during pregnancy in most mammals, including women (Perkoff, Salhanick, Zarrow, Nelson, and Tyler, 1954). Its action, which is blocked by testosterone or adrenal corticosteroids (Brennan and Zarrow, 1957) and increased by oestrogens (Hall, 1947), is to produce changes in the ground substance of pelvic connective tissues leading to relaxation of the pubic symphysis and other pelvic structures. Casten, Boucek, Noble, and Scotti (1956) showed that relaxin given together with oestrogens produced histological and biochemical changes in connective tissue elsewhere than in the pelvis, for example in the rat at the site of an "Ivalon" sponge implant. In this in vivo cultured connective tissue, relaxin caused an increase in the number of mast cells, an increased water content, a reduction of cholesterol synthesis, and the production of fewer, finer, and more widely separated collagen fibres. Because of this, Casten and Boucek (1958) studied relaxin in 23 patients with scleroderma and reported it of value for the vasospasm of associated Raynaud's phenomenon, for the healing of the trophic ulceration, and for decreasing skin tightness. A patient reported by Ismay (1958) with extensive scleroderma with oesophageal involvement improved on relaxin, not only in skin tightness but also as regards dysphagia, and there have been other favourable reports (e.g. Chalmers and Hearnshaw, 1961). Improvement was usually thought to be temporary, but in some, worthwhile remissions were seen even after treatment had stopped.

In the present study a brand of relaxin known as Releasin was used. This product is manufactured in the Warner-Chilcott laboratories from the ovaries of pregnant sows (Albert, Money, and Zarrow, 1947). Releasin is a water-soluble preparation, $1 \mathrm{ml}$. of which contains $20 \mathrm{mg}$. (or 3,000 guinea-pig units) of relaxin standard (one G.P.U. is the amount of relaxin which will induce an unmistakable relaxation of the symphysis pubis in two-thirds of a group of twelve castrated virgin female guinea-pigs weighing between 350 and $380 \mathrm{~g}$.). Each $20-\mathrm{mg}$. ampoule costs 50 s., 20 days' treatment $£ 160$.

Three females suffering from the acrosclerotic type of scleroderma were studied, together with one patient who had a variant of rheumatoid arthritis involving joints and tendon sheaths, with tightening of finger skin, Raynaud's phenomenon, and digital arterial narrowing confirmed by brachial arteriography, and whose hands presented a similar appearance to that of scleroderma.

\section{Case Reports}

Case 1, a woman aged 48, had suffered from Raynaud's phenomenon for 20 years. When aged 47 she first developed painful stiffness of the limbs. 4 months before admission she had noticed tightness, thickening, pigmentation, and itching of the skin of her fingers, arms, upper chest, neck, and face. She suffered from difficulty in chewing, due to the facial tightness, and she showed typical loss of facial creases, narrowing of the palpebral fissures, and $10^{\circ}$ flexion contractures of both elbows. The skin was firmly bound to the joints of her hands, limiting extension of the fingers, and there was a small trophic lesion over the right second proximal interphalangeal joint. The erythrocyte sedimentation rate (Westergren) varied from 8 to $27 \mathrm{~mm}$. in one hour. A full general examination and numerous investigations were entirely compatible with extensive scleroderma without visceral involvement.

Treatment.-The patient had received prednisolone elsewhere and the dosage of this was gradually reduced from 20 to $7.5 \mathrm{mg}$./day, and a priming course of oestradiol benzoate, $1 \mathrm{mg}$. intramuscularly, was given daily. This was changed to Premarin $1.25 \mathrm{mg}$. orally daily after 6 days because of vaginal bleeding. Releasin $20 \mathrm{mg}$. four times a day was then given for 21 days by intramuscular injection. The patient was not told when a 
supposedly active drug was being given and Releasin was presented in a similar manner to the previously administered oestradiol benzoate. The clinical state was assessed by daily measurement of grip strength, range of elbow movement, and width of mouth opening, before, during, and after relaxin. There was considerable desquamation of the skin of the face and arms. The small trophic lesion was uninfluenced by treatment but healed in the observation period after stopping Releasin.

Result.-In the following 6 months, the thickening of skin of the extremities progressed relentlessly and the abdomen and lower limbs became hide-bound. The patient died of oliguric renal failure after 8 months.

Case 2, a woman aged 40, noticed generalized pigmentation at age 31 , followed by secondary Raynaud's phenomenon with recurrent paronychia at age 34 . A bilateral cervical sympathectomy, and later a right dorsal sympathectomy, were followed by temporary improvement. At age 40 painful ischaemic changes occurred in the toes, but improved after a bilateral lumbar sympathectomy. There was a past history of benign hypertension and pre-eclamptic toxaemia of pregnancy.

Examination.--She showed the typical appearance of acrosclerosis, with thickened, smooth, tethered skin over the digits, and atrophy, scarring, and ulceration of the finger tips. The erythrocyte sedimentation rate was $20 \mathrm{~mm}$. in one hour, $x$ rays of the hands showed atrophy of the tufts of the terminal phalanges. A left brachial arteriogram showed severe blockage of digital arteries. Manometric and barium studies showed the characteristic oesophageal changes of systemic sclerosis, and a skin biopsy was reported as typical of scleroderma.

Premarin $1.25 \mathrm{mg}$. was given three times a week for one week before and also during a 2-week course of Releasin (20 mg. intramuscularly four times a day). During and after this therapy there was no appreciable difference in the necrotic ulcerating areas on the terminal phalanges.

COMMENT.-In this patient with scleroderma the outstanding clinical feature was digital ischaemia, which showed no response to Releasin, the cost of which was $£ 112$.

Case 3, a woman aged 42, developed Raynaud's phenomenon in 1955 . In 1960 she suffered from recurrent paronychia which were resistant to treatment. In March, 1961, she noticed tightness of the facial skin and the skin of the chest. Scleroderma was diagnosed and treated with betamethasone $1.5 \mathrm{mg}$. per day by her doctor. She had facial mooning but there was no improvement in her scleroderma. When first seen at Hammersmith she showed classical scleroderma of the fingers, forehead, and front of the chest with telangiectasia of the cheeks and upper chest. There was no systemic involvement.

Investigations. - The sedimentation rate was less than $20 \mathrm{~mm}$./hr. L.E. cells were not seen and the antinuclear factor (Dr. John Holborow, Taplow) was absent.
The differential agglutination test was negative. A chest $x$ ray was normal and a barium meal and follow-through examination were also normal. A left bracinial arteriogram showed narrowing of numerous digital arteries with some thromboses. A reactive hyperaemia test (Pickering, 1933) showed abnormal delay (4 sec.) in all fingers of both hands.

The dose of betamethasone was reduced to 0.25 mg./day and after a 2 weeks' preparation with Premarin $1 \cdot 25 \mathrm{mg}$. three times a week she was given Releasin $20 \mathrm{mg}$. intramuscularly four times a day for 4 weeks. Daily grip strength, the patient's own sensations, and evidence of healing of the paronychia were used as criteria of progress. There was no change in the appearance of the fingers during 4 weeks' Releasin therapy. Grip strength, however, showed improvement and this change was checked by the substitution of a placebo injection for a period of one week and then followed by double the intramuscular dose of Releasin for a further week when there was no corresponding response.

During the period of therapy the patient felt that the skin of the face and chest was more mobile, but this was of course the change she was hoping for, and as it coincided with reduction in "mooning" no conclusion could be drawn.

A second paronychial lesion developed during the course of therapy but quickly healed again.

COMMENT.-This patient had relatively mil\$ $\vec{\varphi}$ scleroderma which showed no significant improve ment with Releasin, the cost of which was $£ 336$.

Case 4, a woman aged 63, had noted pain in shoulders, elbows, arms, and wrists for 4 months, associated with stiffness and weakness in both hands. She had suffered from Raynaud's phenomenon affecting the hands for 10 years.

Examination.-She had a rather smooth face and looked younger than her stated age. The shoulders, elbows, wrists, hips, knees, and ankles were normal. The skin of the fingers was tight, shiny, and bound down over the dorsum of the middle and terminal phalanges. There was limited flexion of all metacarpophalangeal joints and both second proximal interphalangeal joints, with tenderness over these joints on pressure. There was marked thickening of the flexor tendon sheaths in palms and digits of both hands.

Investigations. - The erythrocyte sedimentation rate varied from 55 to $63 \mathrm{~mm} . / 1 \mathrm{hr}$, and the differential 을. agglutination test for rheumatoid arthritis was positive. $\mathrm{N}$ $X$ ray of the hands showed some osteoporosis with two $\sigma$ small erosions of juxta-articular bone. The feet showed $\mathrm{N}$ erosion of the head of the fifth left metatarsal. A biopsy N of the synovium of a finger joint was consistent with $\omega$ rheumatoid synovitis. The barium meal $x$ ray showed decreased oesophageal mobility with slight dilatation $\stackrel{O}{C}$ compatible with early sclerodermatous involvement. $\mathbb{D}$ A right brachial arteriogram showed some blockage of the digital arteries in third, fourth, and fifth fingers con- $\square$ 
sistent with rheumatoid arteritis (Scott, Hourihane, Doyle, Steiner, Laws, Dixon, and Bywaters, 1961).

Whilst she was in hospital both shoulders became very painful with limitation of movement. A diagnosis was made of acute rheumatoid arthritis with marked tendon involvement, with features resembling scleroderma, and this patient was therefore included in the trial.

Treatment.-Releasin $20 \mathrm{mg}$. four times a day by intramuscular injection was given for 2 weeks after 2 weeks of oestrogen priming. Therapy was assessed by daily palm prints (to follow the clawing of the fingers) and daily grip strength. There was minimal improvement in grip strength but no relaxation of the finger contractures.

Follow-up (5 months).--Since her discharge there has been little change except that she has now developed very marked tendon crepitus of the flexor tendons of the second and third fingers of both hands. Erosion of the left ulnar styloid has appeared on $x$ ray.

CommenT.-This patient did not have typical scleroderma, but a variant of rheumatoid arthritis with similar clinical features. The treatment cost £112.

\section{Discussion}

Scleroderma is a disease which varies greatly in severity. Some patients suffer a mild course which is remittent or slowly progressive, whilst others suffer a more fulminant illness with systemic involvement and death. Spontaneous remissions make it difficult to assess the results of therapy. It was felt worth while to report these four cases, each of which was treated with a short intensive course of relaxin, to point out that, in these cases and in the dosage used, this costly drug was without value.

\section{Summary}

Three women with typical scleroderma and one woman with changes resembling both rheumatoid arthritis and scleroderma were each treated with a brand of relaxin four times a day intramuscularly for 2 to 4 weeks. In the dosage used $(20 \mathrm{mg}$.), this form of therapy was without value, despite its cost ( $£ 10$ per day).

We are grateful to Prof. E. G. L. Bywaters and Dr. J. F. Goodwin for permission to publish details of these cases. The work was carried out whilst one of us
(J.E.J.) was holding an Empire Rheumatism Council Travelling Fellowship. The Fellowship was supported by a grant from the Postgraduate Medical Foundation, University of Sydney, Australia.

\section{REFERENCES}

Albert, A., Money, W. L., and Zarrow, M. X. (1947). Endocrinology, 40, 370.

Brennan, D. M., and Zarrow, M. X. (1957). Fed. Proc., $16,14$.

Casten, G. G., and Boucek, R. J. (1958). J. Amer. med. Ass., 166, 319.

,-- , Noble, N. L., and Scotti, T. N. (1956). Amer. J. Med., 20, 943.

Chalmers, T. N., and Hearnshaw, J. R. (1961). Ann. rheum. Dis., 20, 202.

Frieden, E. H., and Hisaw, F. L. (1953). Recent Progr. Hormone Res., 8, 333.

Hall, K. (1947). J. Endocr., 5, 174.

Hisaw, F. L. (1926). Proc. Soc. exp. Biol. (N.Y.), 23,661 .

Ismay, G. (1958). Brit. J. Derm., 70, 171.

Perkoff, G. T., Salhanick, H. A., Zarrow, M. X., Nelson, D. H., and Tyler, F. H. (1954). J. clin. Endocr., 14, 531 .

Pickering, G. W. (1933). Brit. med. J., 2, 1106.

Scott, J. T., Hourihane, D. O., Doyle, F. H., Steiner, R. E., Laws, J. W., Dixon, A. St. J., and Bywaters, E. G. L. (1961). Ann. rheum. Dis., 20, 224.

Echec de la Relaxin dans le traitement de la sclérodermie

RÉSUMÉ

Trois femmes atteintes de sclérodermie typique et une femme accusant des symptômes d'arthrite rhumatismale et de sclérodermie furent traitées par une marque de relaxin quatre fois par jour, par voie intramusculaire, pendant 2 à 4 semaines. En dose employée $(20 \mathrm{mg}$.), cette forme de thérapie fut sans valeur, malgré son prix (£10 par jour).

Fracaso de la Relaxin en el tratamiento de la esclerodermia

\section{SUMARIO}

Tres mujeres con esclerodermia típica y una con síntomas de artritis reumatoide y de esclerodermia fueron tratadas con una marca de relaxin cuatro veces al día, por vía intramuscular, durante 2 a 4 semanas. En dosis empleada $(20 \mathrm{mg}$.) esta forma terapéutica fué sin valor, a pesar de su precio ( $£ 10$ al día). 